\title{
The incidence, pattern and management of sexual assault in a tertiary hospital in North-western Nigeria
}

\author{
Constance E. Shehu ${ }^{1 *}$, Ojogbane I. Ekele ${ }^{1}$, Abubakar A. Panti ${ }^{1}$, Ibrahim Ango ${ }^{1}$, \\ Bissallah A. Ekele ${ }^{2}$, Mohammed Umar'
}

${ }^{1}$ Department of Obstetrics and Gynaecology, Usmanu Danfodiyo University Teaching Hospital, Sokoto, Nigeria
${ }^{2}$ Department of Obstetrics and Gynaecology, University of Abuja Teaching Hospital, Gwagwalada, FCT, Nigeria

Received: 01 July 2019

Accepted: 14 August 2019

*Correspondence:

Dr. Constance E. Shehu,

E-mail: doctorkonstance@gmail.com

Copyright: (c) the author(s), publisher and licensee Medip Academy. This is an open-access article distributed under the terms of the Creative Commons Attribution Non-Commercial License, which permits unrestricted non-commercial use, distribution, and reproduction in any medium, provided the original work is properly cited.

\begin{abstract}
Background: Sexual assault is any sexual act performed by one person on another without the person's consent or on a victim who is incapable of giving consent. It is a violation of basic human rights, a gender-based issue and a violent crime against both the individual and the society. The objectives of the study were to determine the incidence, pattern and management of sexual assault in Usmanu Danfodiyo University Teaching Hospital, Sokoto, Nigeria.

Methods: This was a 10 - year retrospective study. Case records of sexual assault from $1^{\text {st }}$ January, 2007 to $31^{\text {st }}$ December, 2016 were retrieved and relevant data extracted and analyzed using the SPSS for windows version 20.0

Results: The incidence of sexual assault was $0.8 \%$. Majority, $88(85.4 \%)$ occurred in children and adolescents. Penovaginal penetration was the most common form of assault $65(63.1 \%)$ and the assailants were known to the victims in $74(71.9 \%)$ of the cases. Involvement of psychiatrists/psychologists in the management of the victims was poor as psychiatrists were involved in only $13(12.6 \%)$ of the cases. Most of the victims were lost to follow up.

Conclusions: Sexual assaults occurred mostly in children and adolescents in this study. Increased public awareness and preventive interventions are required especially among the at-risk age groups to enhance their safety. Training of relevant persons in the institution to offer counselling to the victims is recommended as referral for psychiatrists' consultation was poor. It is important to institute a good tracking system to follow up the victims as most are lost to follow up.
\end{abstract}

Keywords: Children and adolescents, Psychiatrists/psychologists, Sexual assault, Victims

\section{INTRODUCTION}

The term "sexual assault", "sexual abuse" and "sexual violence" are generally used synonymously. ${ }^{1}$ According to the World Health Organization (WHO), sexual violence is defined as "any sexual act, attempt to obtain a sexual act, unwanted sexual comments or advances, or acts to traffic or otherwise directed against a person's sexuality using coercion, by any person regardless of their relationship to the victim, in any setting, including but not limited to home or work". 2 It is a violation of basic human rights, gender-based issue and a violent crime against the individual and the society. ${ }^{1,3}$

Sexual assault is a severely traumatic experience that disproportionately affects women and girls. ${ }^{4}$ It is a pandemic crime that is characteristically under-reported worldwide. This is because of the enduring culture or male dominance, female social and economic disempowerment, poor or non-prosecution of sex offenders, arduous legal requirement needed to prove the cases and the associated stigma. ${ }^{4}$ 
According to $\mathrm{WHO}$, one in every five women is a victim of sexual assault and globally, 35\% of women experience either physical and/or sexual intimate partner violence or non-partner sexual violence. ${ }^{5,6}$ In Nigeria, the prevalence of rape from facility-based studies vary from $2.1 \%$ in Osogbo to $5.6 \%$ in Jos of all gynaecological consultations. $^{7,8}$ A prevalence of $51.3 \%$ of sexual assaults was reported among female students in a tertiary institution in Maiduguri, Nigeria, while $3.0 \%$ of sexual violence was reported among women and children in Birnin Kudu by Ashimi AO et al. In Ile-Ife, sexual assault accounted for $0.69 \%$ of all female emergency admissions. . $^{1,3,9}$

Sexual assault include genital, oral or anal penetration by a part of the accused's body or by an object. ${ }^{10}$ This may include rape, forced vaginal, anal or oral penetration, forced sexual intercourse, inappropriate touching, forced kissing, child sexual abuse or torture of the victim in a sexual manner. ${ }^{3}$ Although peno-vaginal penetration or attempted penetration is the commonest form of sexual assault, penile penetration or attempted penetration of the anus or mouth without consent is increasingly being reported. ${ }^{4}$

The assailant usually ranges from a person close to the victim like a relative, neighbour, friend, school mate, teacher, caregiver, husband or guardian to a stranger. ${ }^{3}$ It has been found that women are more likely to be raped by someone they know than by someone they do not know. ${ }^{3}$

Most of the sexual assaults occur in the residence of the victim, the assailant or another individual's residence; other prevalent locations are street, commercial building, and inside a school building or property. ${ }^{3}$

Sexual assault is a crime of violence that puts the victim at risk of physical injury, psychological disturbance, emotional disturbance, pregnancy and sexually transmitted diseases including human immunodeficiency virus (HIV) infection. ${ }^{3,11}$ Somatic symptoms are common during the acute phases of the rape-trauma syndrome. These include musculoskeletal soreness, fatigue, tension headache, sleeping and eating disorders, intense startle reaction, vaginal irritation and bleeding. ${ }^{12}$ Although the trauma of the assault heals with time, it leaves long term psychological and medical problems behind. ${ }^{13}$ The psychological sequelae of sexual assault can be profound; approximately $50 \%$ of victims experience depression. ${ }^{3}$

The standard of clinical management of sexual violence involves documentation and treatment of injury, getting forensic materials, detecting prior pregnancy, screening for sexually transmitted infections including Human Immunodeficiency virus (HIV) and provision of adequate contraception, post-exposure prophylaxis (PEP) and supporting psychological counseling. ${ }^{4}$
As in most other developing countries, sexual assaults go mostly unreported in the subregion. Hence, the need for this audit. The objectives of the study therefore, are to determine the incidence, pattern of presentation and management of sexual assaults in Usmanu Danfodiyo University Teaching Hospital, Sokoto, North-West Nigeria.

\section{METHODS}

The study was conducted at the Usmanu Danfodiyo Teaching Hospital, Sokoto, North-west Nigeria. Usmanu Danfodiyo University Teaching Hospital is a tertiary hospital that renders preventive, promotive and curative services. It serves as a referral centre for Sokoto, Zamfara and Kebbi states as well as part of Niger Republic. It was a facility based descriptive retrospective study. All cases of sexual assault that presented to the hospital from January, $1^{\text {st }} 2007$ to December, $31^{\text {st }} 2016$ were reviewed. The numbers of the folders of cases of sexual assaults were obtained from the Health Records department of the hospital and the folders were subsequently retrieved manually. Relevant data was extracted from the folders using a designed proforma and analysed using the SPSS for windows version 20.0. Results are presented in percentages.

\section{Inclusion criteria}

All cases of sexual assault that presented to the study area within the review period were included.

\section{Exclusion criteria}

All other causes of assault were excluded from the study.

\section{RESULTS}

A total of 14,904 patients were seen in the Gynaecological out-patient and emergency clinics over the review period with 119 of them being cases of sexual assault. This gave an incidence of $0.8 \%$. Of the 119 cases 103 case-folders were retrieved for analysis giving a retrieval rate of $86.6 \%$.

\section{Socio-demographic characteristics of the victims}

The mean age of the victims was $11.6 \pm 7.95$ years while the age range was 2-37 years. The most commonly assaulted age group was age $<10$ years involving 47 $(45.6 \%)$. All the victims were female and $92(89.3 \%)$ of them were single. Most of the victims, 70 (68.0\%), were of Hausa/Fulani ethnicity and $72(69.9 \%)$ of the victims were Muslims. Primary school pupils were the most commonly assaulted victims $35(34.0 \%$ ) (Table 1$)$.

\section{Profile of assailants}

All the assailants were male and majority of them were known to the victims ranging from neighbours 46 
(44.7\%), friends $10(9.7 \%)$, acquaintances $10(9.7 \%)$ and family members $8(7.8 \%)$. Only one assailant was involved in $89(86.4 \%)$ of the cases. Only $41(39.8 \%)$ assailants were arrested.

Table 1: Socio-demographic characteristics of the victims.

\begin{tabular}{|c|c|c|}
\hline Characteristic & Frequency & Percentage \\
\hline \multicolumn{3}{|l|}{ Age } \\
\hline$<10$ & 47 & 45.6 \\
\hline $10-19$ & 41 & 39.8 \\
\hline $20-29$ & 9 & 8.8 \\
\hline$\geq 30$ & 6 & 5.8 \\
\hline \multicolumn{3}{|l|}{ Sex } \\
\hline Female & 103 & 100 \\
\hline Male & 0 & 0 \\
\hline \multicolumn{3}{|l|}{ Educational status } \\
\hline Pre-school & 15 & 14.6 \\
\hline No formal education & 29 & 28.1 \\
\hline Primary & 35 & 34.0 \\
\hline Secondary & 15 & 14.6 \\
\hline Tertiary & 9 & 8.7 \\
\hline \multicolumn{3}{|l|}{ Occupation } \\
\hline Under care & 27 & 26.2 \\
\hline Primary school pupil & 32 & 31.1 \\
\hline Secondary school student & 17 & 16.5 \\
\hline Tertiary student & 6 & 5.8 \\
\hline NYSC member & 1 & 1.0 \\
\hline Not indicated & 20 & 19.4 \\
\hline \multicolumn{3}{|l|}{ Marital status } \\
\hline Single & 92 & 89.3 \\
\hline Married & 8 & 7.8 \\
\hline Divorced & 3 & 2.9 \\
\hline \multicolumn{3}{|l|}{ Tribe } \\
\hline Hausa/Fulani & 70 & 68.0 \\
\hline Igbo & 12 & 11.6 \\
\hline Yoruba & 8 & 7.8 \\
\hline Others & 13 & 12.6 \\
\hline \multicolumn{3}{|l|}{ Religion } \\
\hline Islam & 72 & 69.9 \\
\hline Christianity & 31 & 20.1 \\
\hline
\end{tabular}

Only $20(19.4 \%)$ and $15(14.5 \%)$ of the assailants were screened for HIV and hepatitis B virus respectively. Two of the assailants were reactive to hepatitis B virus while all were non-reactive to HIV (Table 2).

\section{Pattern of assaults}

The most common location of sexual assault was in the assailants' house in $48(46.6 \%)$ of the cases.

The victims were subdued by use of force in $38(36.9 \%)$ of the cases. Weapons were used in $18(17.5 \%)$ of the cases and the most commonly used weapon was knife/cutlass. Peno-vaginal intercourse was the most common assault reported in $65(63.1 \%)$ cases (Table 3 ).

Table 2: Profile of assailants.

\begin{tabular}{|c|c|c|}
\hline Profile & Frequency & Percentage \\
\hline \multicolumn{3}{|l|}{ Identity } \\
\hline Neighbour & 46 & 44.7 \\
\hline Stranger & 24 & 23.3 \\
\hline Friend & 10 & 9.7 \\
\hline Acquaintance & 10 & 9.7 \\
\hline Family member/Relation & 8 & 7.8 \\
\hline Armed robber & 3 & 2.9 \\
\hline Not documented & 2 & 1.9 \\
\hline \multicolumn{3}{|l|}{ Age of assailant(s) } \\
\hline$<15$ & 5 & 4.9 \\
\hline $15-24$ & 10 & 9.7 \\
\hline $25-34$ & 13 & 12.6 \\
\hline$\geq 35$ & 4 & 3.9 \\
\hline Not documented/unknown & 71 & 68.9 \\
\hline \multicolumn{3}{|l|}{ Sex } \\
\hline Male & 103 & 100 \\
\hline Female & 0 & 0.0 \\
\hline \multicolumn{3}{|l|}{ Occupation } \\
\hline Commercial driver & 2 & 1.9 \\
\hline Motor cyclist (Okada) & 4 & 3.9 \\
\hline Trader & 8 & 7.8 \\
\hline Farmer & 6 & 5.8 \\
\hline Civil servant & 5 & 4.9 \\
\hline Student & 9 & 8.7 \\
\hline House help & 2 & 1.9 \\
\hline Artisan & 8 & 7.8 \\
\hline Thug & 4 & 3.9 \\
\hline Security guard & 5 & 4.9 \\
\hline Armed robber & 3 & 2.9 \\
\hline Not documented/unknown & 47 & 45.6 \\
\hline \multicolumn{3}{|l|}{ Number of assailant(s) } \\
\hline One & 89 & 86.4 \\
\hline Two & 13 & 12.6 \\
\hline Six & 1 & 1.0 \\
\hline \multicolumn{3}{|l|}{ Arrest of assailant(s) } \\
\hline Yes & 41 & 39.8 \\
\hline No & 62 & 60.2 \\
\hline \multicolumn{3}{|l|}{ HIV Status } \\
\hline Reactive & 0 & 0.0 \\
\hline Non-reactive & 20 & 19.4 \\
\hline Not known/not done & 83 & 80.6 \\
\hline \multicolumn{3}{|l|}{ Hepatitis B Status } \\
\hline Reactive & 2 & 1.9 \\
\hline Non-reactive & 13 & 12.6 \\
\hline Not known/not done & 88 & 85.5 \\
\hline
\end{tabular}

\section{Pattern of presentation}

The most common time of presentation was 6-12 hours after the assault in $28(271 \%)$ of cases. In $56(54.4 \%)$ of 
the cases, the victims were brought to the hospital by their parents/caregivers/relatives. In 60 (58.3\%) of cases, the assault was reported to the police before presentation. Many, $48(46.6 \%)$ of the victims bathed before presentation. The most common presenting symptoms was vaginal bleeding in 34 (33\%) victims (Table 4$)$.

Table 3: Pattern of assaults.

\begin{tabular}{|c|c|c|}
\hline Pattern & Frequency & Percentage \\
\hline \multicolumn{3}{|l|}{ Place of assault } \\
\hline Assailant's house & 48 & 46.6 \\
\hline Victim's house & 10 & 9.7 \\
\hline School/classroom & 4 & 3.9 \\
\hline Uncompleted building & 15 & 14.6 \\
\hline Roadside & 5 & 4.9 \\
\hline Bush/farm & 13 & 12.6 \\
\hline Toilet & 5 & 4.9 \\
\hline Not documented & 3 & 2.9 \\
\hline \multicolumn{3}{|c|}{ Method used to subdue victim } \\
\hline Verbal threat & 13 & 12.6 \\
\hline Use of force & 38 & 36.9 \\
\hline Verbal threat and use of force & 5 & 4.9 \\
\hline Enticement and use of force & 1 & 1 \\
\hline Enticement only & 18 & 17.5 \\
\hline Deception & 25 & 24.5 \\
\hline Use of sedative & 1 & 1 \\
\hline Not documented & 2 & 2 \\
\hline \multicolumn{3}{|l|}{ Use of weapon } \\
\hline Yes & 18 & 17.5 \\
\hline No & 85 & 82.5 \\
\hline \multicolumn{3}{|l|}{ Weapon(s) used } \\
\hline Knife/matchet & 8 & 44.4 \\
\hline Gun & 2 & 11.2 \\
\hline Club/stick & 4 & 22.2 \\
\hline Stone & 4 & 22.2 \\
\hline \multicolumn{3}{|l|}{ Type of sexual assault } \\
\hline Fondling & 13 & 12.6 \\
\hline $\begin{array}{l}\text { Peno-vaginal penetration } \\
\text { only }\end{array}$ & 65 & 63.1 \\
\hline Peno-oral & 1 & 1.0 \\
\hline Peno-vaginal and peno-oral & 2 & 1.9 \\
\hline $\begin{array}{l}\text { Insertion of fingers into the } \\
\text { vagina }\end{array}$ & 15 & 14.6 \\
\hline $\begin{array}{l}\text { Fondling and peno-vaginal } \\
\text { penetration }\end{array}$ & 3 & 2.9 \\
\hline $\begin{array}{l}\text { Fondling, peno-vaginal and } \\
\text { insertion of fingers into } \\
\text { vagina }\end{array}$ & 4 & 3.9 \\
\hline
\end{tabular}

\section{Investigations performed for victims}

Most, 67 (65\%) of the victims were screened for HIV and all were non-reactive. Three of the victims had a positive pregnancy test at the time of assault. Only 40 (38.8\%) of the victims were screened for hepatitis B virus. Vaginal aspirate for microscopy was positive for spermatozoa in 6 victims. Grouping and cross-matching of blood was requested in only 2 victims (Table 5).

Table 4: Pattern of presentation.

\begin{tabular}{|c|c|c|}
\hline & Frequency & Percentage \\
\hline \multicolumn{3}{|c|}{ Interval before presentation (hours) } \\
\hline$<6$ & 25 & 24.3 \\
\hline $6-12$ & 28 & 27.2 \\
\hline $13-24$ & 30 & 29.1 \\
\hline $25-36$ & 3 & 2.9 \\
\hline $37-48$ & 4 & 3.9 \\
\hline$>48$ & 13 & 12.6 \\
\hline \multicolumn{3}{|l|}{ Brought to hospital by } \\
\hline Self & 6 & 5.8 \\
\hline Parents/caregivers/relations & 56 & 54.4 \\
\hline Law enforcement agents & 3 & 2.9 \\
\hline $\begin{array}{l}\text { Parents and law } \\
\text { enforcement agents }\end{array}$ & 30 & 29.1 \\
\hline School authority & 6 & 5.8 \\
\hline Not documented & 2 & 2.0 \\
\hline \multicolumn{3}{|c|}{ Actions taken prior to presentation } \\
\hline Bathing & 48 & 46.6 \\
\hline Douching & 44 & 42.7 \\
\hline Changed/washed clothing & 42 & 40.8 \\
\hline Reported to the Police & 60 & 58.3 \\
\hline \multicolumn{3}{|l|}{ Mode of presentation } \\
\hline Vaginal bleeding & 34 & 33.0 \\
\hline Vaginal discharge & 21 & 20.4 \\
\hline Vaginal laceration & 16 & 15.5 \\
\hline Perineal lacerations/bruises & 8 & 7.8 \\
\hline Urinary symptoms & 7 & 6.8 \\
\hline Lower abdominal pain & 16 & 15.5 \\
\hline Musculoskeletal injury & 13 & 12.6 \\
\hline
\end{tabular}

\section{Treatment received by the victims}

Prophylactic antibiotics for sexually transmitted infections was received by $84(81.6 \%)$ of the victims and it was the most common treatment received. Few, 15 (14.6\%) patients had examination under anaesthesia while $13(12.6 \%)$ victims had repair of laceration. The psychiatrists were involved in only $13(12.6 \%)$ of the cases while only $17(16.5 \%)$ victims came for at least one follow-up visit (Table 6).

\section{Involvement of law enforcement agents and arrest of assailants}

The law enforcement agents were involved in $66(64.1 \%)$ of the cases. The parents reported $50(75.8 \%)$ of the cases to the law enforcement agents but only 41 (39.8\%) of the assailants were arrested (Table 7).

\section{DISCUSSION}

The prevalence of sexual assault in this study is $0.8 \%$. This is comparable to $0.69 \%$ from Ile-Ife (Ife), $0.76 \%$ in 
Lagos but less than $2.1 \%, 2.2 \%, 3 \%, 5.6 \%, 7.7 \%$ and $13.8 \%$ reported in Osogbo, Calabar, Birnin Kudu, Jos, Benin-City and Maiduguri respectively. 1,7,8,11,14,15 The low incidence of sexual assault in this study may be a 'tip of iceberg' of what is obtains in the community as sexual assault is not uncommon in Nigeria but few of the cases are usually reported.

Table 5: Investigations performed for victims.

\begin{tabular}{|lll|}
\hline Investigation & Frequency & Percentage \\
\hline HIV screening & \multicolumn{2}{l|}{} \\
\hline Reactive & 0 & 0.0 \\
\hline Non-reactive & 67 & 65.0 \\
\hline Not done & 36 & 35.0 \\
\hline Hepatitis B screening & & \\
\hline Reactive & 0 & 0.0 \\
\hline Non-reactive & 40 & 38.8 \\
\hline Not done & 63 & 62.2 \\
\hline Pregnancy test & & \\
\hline Positive & 3 & 2.9 \\
\hline Negative & 20 & 19.4 \\
\hline Not done & 80 & 77.7 \\
\hline Vaginal aspirate for microscopy & \\
\hline $\begin{array}{l}\text { Positive for } \\
\text { spermatozoa }\end{array}$ & 6 & 5.8 \\
\hline $\begin{array}{l}\text { Negative for } \\
\text { spermatozoa }\end{array}$ & 33 & 32.0 \\
\hline Not done & 64 & 62.2 \\
\hline Grouping and cross matching of blood \\
\hline Done & 2 & 1.9 \\
\hline Not done & 101 & 98.1 \\
\hline Ultrasonography & 2 & 98.1 \\
\hline Done & 102 & \\
\hline Not done & & \\
\hline
\end{tabular}

Table 6: Treatment received by the victims.

\begin{tabular}{|lll|}
\hline Treatment & Frequency & Percentage \\
\hline $\begin{array}{l}\text { STI antibiotic } \\
\text { prophylaxis }\end{array}$ & 84 & 81.6 \\
\hline HIV PEP & 47 & 45.6 \\
\hline $\begin{array}{l}\text { Emergency } \\
\text { contraception }\end{array}$ & 23 & 22.3 \\
\hline EUA & 15 & 14.6 \\
\hline Repair of laceration & 13 & 12.6 \\
\hline $\begin{array}{l}\text { Involvement of } \\
\text { Psychiatrist }\end{array}$ & 13 & 12.6 \\
\hline Follow up & 17 & 16.5 \\
\hline
\end{tabular}

Majority, 47 (45.6\%) of the victims in this study were in the age group of less than 10 years of age followed by age range of 10-19 years of age which constituted $39.8 \%$ of the victims. This is in agreement with other studies where disproportional numbers of sexual assault victims are children and adolescents. ${ }^{1,4,9,16,17}$
Table 7: Involvement of law enforcement agents and arrest of assailants.

\begin{tabular}{|c|c|c|}
\hline & Frequency & Percentage \\
\hline \multicolumn{3}{|c|}{ Involvement of law enforcement agents } \\
\hline Yes & 66 & 64.1 \\
\hline No & 37 & 35.9 \\
\hline \multicolumn{3}{|c|}{ Law enforcement agents involved by $(n=66)$} \\
\hline Parents/caregivers/relations & 50 & 75.8 \\
\hline Victims & 14 & 21.1 \\
\hline Others & 12 & 3.1 \\
\hline \multicolumn{3}{|l|}{ Arrest of assailants } \\
\hline Yes & 41 & 39.8 \\
\hline No & 62 & 60.2 \\
\hline
\end{tabular}

All the victims of sexual assault in this study were females. This differs from reports from Zaria and Lagos in Nigeria, India, Uganda and South Africa where male victims were reported. ${ }^{16-21}$

Most of the victims, $(89.3 \%)$ in the study were not married. This is in tandem with other studies from different parts of the country. ${ }^{1,9,16,17}$

There was scanty information about the assailants however the assailants were known to the victims in 71.9 $\%$ of the cases and they ranged from neighbors, friends, acquaintances to family members/relatives; and all were male. This agrees with findings in previous surveys. ${ }^{1,4,9,22}$ One assailant was involved in $86.4 \%$ of the cases with one occurrence of gang rape involving 6 assailants. This was comparable to other studies in which one assailant was involved in the majority of the cases. ${ }^{1,9,16,17}$ The assailants were arrested only in $39.8 \%$ of the cases. This is comparable to $33.8 \%$ arrest of assailants reported in Ile-Ife. ${ }^{9}$ Out of the arrested assailants; only $19.4 \%$ and $14.5 \%$ were screened for retroviral disease and hepatitis respectively.

Many, $46.6 \%$ of the assaults took place in the assailant's house. This is similar to findings from Birnin Kudu, IleIfe, Port-Harcout and Lagos where most of the assaults occurred in the assailants' houses. ${ }^{1,9,16,22}$

Use of force was the most common method applied in subduing the victims in $36.9 \%$ of the cases. This differs from use of verbal threats in majority of cases reported in Birnin Kudu, Ile-Ife and Lagos., ${ }^{1,9,16}$ Weapons were employed in only $17.5 \%$ of the cases and the most commonly used weapon was knife/matchet. This is different from the finding in Ile-Ife where the most commonly used weapon was firearms. ${ }^{9}$

The most common form of assault in this study was penovaginal intercourse alone in $63.1 \%$. This is similar to the finding in Ile-Ife but differs from the finding in PortHarcourt in which fondling/grabbing of sensitive body parts was the highest form of sexual assault experienced by the victims. ${ }^{9,22}$ 
Most of the victims (51.4\%) presented to the hospital within 12 hours of the assault. This is comparable to the findings in Osogbo and Ile-Ife in which majority of the victims presented within 24 hours of the assault but different from that of other studies in which the majority of the victims presented after 24 hours to greater than 72 hours. . $^{7,1,8,16,17}$

The most common presenting symptom in the study was vaginal bleeding $(33.0 \%)$ while $15.5 \%$ had vaginal laceration. This is not surprising as the majority of the cases of assault in this study occurred in children and for obvious anatomical reasons, children are more likely to suffer genital trauma.

Only $65 \%$ of the victims were screened for Human Immunodeficiency Virus (HIV) in this review. This is higher than $45.5 \%$ reported in Birnin Kudu but less than $72.3 \%$ and $84.5 \%$, 95\% reported in Lagos, Ile-Ife and Zaria respectively. ${ }^{1,9,16,17}$ Similarly, only $38.8 \%$ were screened for Hepatitis B virus in the study. This was also higher than $10.0 \%$ reported in Birnin Kudu but less than $33.8 \%$ reported from Ife and $50.5 \%$ from Lagos. ${ }^{1,4,9}$ These investigations (RVS and HBV among others) were requested in all the patients at presentation but most could not be done in most cases due to financial constraints as patients pay for out-of-pocket for services in our institution.

The most common form of treatment received by victims in this study was antibiotic prophylaxis against sexually transmitted infection in $81.6 \%$ of the cases. This was similar to findings in Zaria and Ile-Ife. ${ }^{9,17}$ Only $45.6 \%$ of the victims received post-exposure prophylaxis for HIV in this research. This was higher than $25.5 \%$ reported in Lagos but less than $52.1 \%$ in Ile-Ife, $90.3 \%$ in another study from Lagos. ${ }^{4,9,16}$

Emergency contraception was received by only $22.3 \%$ of the victims. This was in keeping with other studies where emergency contraception to prevent post-rape pregnancy was consistently low but contrary to the finding in Lagos where $95.0 \%$ of the victims received emergency contraception. ${ }^{4,9,16,23}$

The low rate of administration of emergency contraception in this study may not be unconnected to the fact that majority of the victims in this study were prepubertal girls.

Psychiatrists were involved in the management of just $12.6 \%$ of the victims. This was in keeping with the findings from others studies in which the involvement of psychiatrists/psychologists was poor. ${ }^{16,17}$

Majority of the victims in this study were lost to follow up as only $16.5 \%$ of the victims had at least one followup visit. This is different from the finding in Lagos where about $75 \%$ came for follow-up but similar to others studies in which majority of the victims were lost to follow up..$^{1,9,16,17}$ The dismal follow-up performance may not be unconnected with the stigma usually attached to sexual assault victims in general.

\section{CONCLUSION}

Sexual assault is a violation of basic human rights. The incidence may be low in this study but it reaffirms that sexual assault is a major adolescent reproductive health problem and uncovers the stark reality of child sexual abuse in Sokoto as found in other studies. Assailants are known in most cases and neighbours constituted the majority of the assailants.

All parents, therefore, need to be mindful of this risk when leaving their children alone with anyone. Increased public awareness and preventive interventions are required especially among the at-risk age group to enhance their safety.

\section{Recommendations}

Compulsory screening of assailants for sexual transmitted infections is recommended as less than $50 \%$ of the assailants were screened for HIV and hepatitis B virus in this study. Similarly, treatment of sexual assaults in the hospital should be made free or subsidized to enable most victims receive the required treatment which may be hindered by financial constraints. Involvement of the psychiatrists and follow up was poor in this study. Training of relevant persons in the institution to offer counselling to the victims is recommended. It is also important to institute a good tracking system to follow up these victims to determine the success of the treatment, to provide emotional and psychological supports as well as treat long term sequalae arising from the assaults.

\section{ACKNOWLEDGMENTS}

Authors would like to thank medical record staff of the Teaching hospital for their support during study.

Funding: No funding sources

Conflict of interest: None declared

Ethical approval: The study was approved by the Institutional Ethics Committee

\section{REFERENCES}

1. Ashimi AO, Amole TG, Ugwa EA. Reported sexual violence among women and children seen at the gynaecological emergency unit of a rural tertiary health facility, North West Nigeria. Ann Med Health Sci Res. 2015;5:26-9.

2. World Health Organization. Intimate partner and sexual violence against women. Available at: apps.who.int/iris/bitstream/10665/77432/1/WHO_R HR_12.36_eng.pdf. 2011.

3. Geidam AD, Njoku AE, Bako B. Prevalence and nature of sexual assault among female students in a 
tertiary institution in Maiduguri, Nigeria- A crosssectional study. Int J Health Res. 2010;3(4):199-203.

4. Akinsuli FM, Rabiu K, Olawepo T, Adewumi AA, Ottun TA, Akinola OI. Sexual assault in Lagos, Nigeria: a five-retrospective review. BMC Women's Health. 2014;14:115.

5. Garcia MC, Watts C. Violence against women: an urgent public health priority. Bulletin of the World Health Organization. 2011;89:2-8.

6. World Health Organization. Global and regional estimates of violence against women. Prevalence and health effects of intimate partner violence and nonpartner sexual violence. Available at: http://www.who.int/reproductivehealth/publications/ violence/9789241564625/en/. 2013.

7. Adeleke NA, Okowookere AS, Hassan MB, Komolafe JO, Asekun OEO. Sexual assault against women at Osogbo, Southwestern Nigeria. Niger J Clin Pract. 2012;15:190-3.

8. Daru PH, Osagie EO, Pam IC, Mutihir JT, Silas OA, Ekwempu CC. Analysis of cases of rape as seen at the Jos University Teaching Hospital, Jos, North central Nigeria. Niger J Clin Pract. 2011;14:47-51.

9. Badejoko OO, Anyabolu HC, Badejoko BO, Ijarotimi AO, Kuti O, Adejuyigbe EA. Sexual assault in Ile-Ife, Nigeria. Niger Med J. 2014;55:254-9.

10. Lu MC, Lu JS, Halfin VP. Domestic violence and sexual assault. In: Decherney AH, Nathan L, Laufer N, Roman AS, (Eds.). Current Diagnosis and Treatment Obstet Gynecol $11^{\text {th }}$ ed. New York: Mc Graw Hill Medical; 2013:971-977.

11. Ekabua JE, Agan TU, Iklaki CU, Ekanem EI, Itam IH, Ogaji DS. Risk factors associated with sexual assault in Calabar, Southeastern Nigeria. Niger J Med. 2006;15:406-8.

12. Ekabua JE, Agan TU, Iklaki CU, Ekanem EI, Itam IH, Ogaji DS. Trauma related to sexual assault in Calabar, Southeastern Nigeria. Niger $\mathrm{J}$ Med. 2006;15(1):72-4.

13. Violence against women - World Health Organization. Available at: https://www.who.Int/news-room /fact-sheets/detail /violence-against-women . 2016.
14. Akhiwu W, Umanah IN, Olueddo AN. Sexual assault in Benin-City, Nigeria. TAF Prev Med Bull. 2013;12(4):377-82.

15. Audu B, Geidam A, Jarma H. Child labour and sexual assault among girls in Maiduguri, Nigeria. Int J Gynaecol Obstet. 2009;104(1):64-7.

16. Ezechi OC, Musa ZA, David AN, Wapmuk AE, Gbajabiamila TA, Idigbe IE. Trends and patterns of sexual assaults in Logaos, South-Western Nigeria. Pan Afr Med J. 2016;24:261.

17. Bugaje MA, Ogunrinde GO, Faruk JA. Child sexual abuse in Zaria, North Western Nigeria. Niger J Paed. 2012;39(3):110-4.

18. Lakew Z. Alleged cases of sexual assault reported to two Addis Ababa hospitals. East Afr Med J 2001;78:80-3.

19. Raj A, McDougal L. Sexual violence and rape in India. Lancet. 2014;8:383-6.

20. Onange S, Wandabwa J, Kiondo P, Busingye R. Clinical presentation and management of alleged sexually assaulted females at Mulago hospital, Kampala, Uganda. Afr Health Sci. 2005;29(1):50-4.

21. Jewkes R, Abrahams N. The epidemiology of rape and sexual coercion in South Africa. Social Sci Med. 2002;55(7):1231-44.

22. Margaret MMI, Mezie O, Folusho A. Sexual violence among female undergraduates in a tertiary institution in Port-Harcourt: prevalence, pattern, determinants and health consequences. Afr J Reprod Health. 2014;18(4):79-85.

23. Martin SL, Young SK, Billings DL, Bross CC. Health care-based interventions for women who have experienced sexual violence: A review of the literature. Trauma Violence Abuse. 2007;8(1):3-18.

Cite this article as: Shehu CE, Ekele OI, Panti AA, Ango1 I, Ekele BA, Umar M. The incidence, pattern and management of sexual assault in a tertiary hospital in North-western Nigeria. Int J Reprod Contracept Obstet Gynecol 2019;8:3715-21. 